\title{
Early Onset of Axonal Degeneration in Double (p/p-/-mag-/-) and Hypomyelinosis in Triple (p/p-/-mbp-/-mag-/-) Mutant Mice
}

\author{
Thomas Uschkureit,, ${ }^{1}$ Olaf Spörkel, ${ }^{1}$ Jens Stracke, ${ }^{1}$ Heinrich Büssow, ${ }^{2}$ and Wilhelm Stoffel ${ }^{1}$ \\ ${ }^{1}$ Laboratory for Molecular Neuroscience, University of Cologne, D-50931 Cologne, Germany, and 2Institute of Anatomy, \\ University of Bonn, D-53115 Bonn, Germany
}

Double ( $p / p-/-m a g-/-)$ and triple ( $p / p-/-m b p-/-m a g-/-)$ null-allelic mouse lines deficient in proteolipid protein (PLP), myelin-associated glycoprotein (MAG), and myelin basic protein (MBP) were generated and characterized genetically, biochemically, and morphologically including their behavioral capacities. The $p / p-/-m a g-/-$ mutant develops a rapidly progressing axon degeneration in CNS with severe cognitive and motor coordinative deficits but has a normal longevity. CNS axons of the $p / p-/-m b p-/-m a g-/-$ mouse are hypomyelinated and ensheathed by "pseudomyelin" with disturbed protein and complex lipid composition. The shiverer trait in the $p / p-/-m b p-/$ - mag $-/-$ similar to the $p l p-/-m b p-/-$ mutant is significantly ameliorated, and its lifespan is considerably prolonged. The longevity of these dysmyelinosis mouse mutants recommends them as suitable models for the long-term evaluation of stem cell therapeutic strategies.

Key words: double mutants; triple mutant; myelin proteins; myelin lipids; ultrastructure of myelin; behavioral tests
Myelination of axons by oligodendrocytes in the CNS and Schwann cells in the PNS of vertebrates is an important event in the early development. In the CNS oligodendrocytes synthesize myelin specific proteins and lipids in a stringently regulated temporal sequence and assemble them in plasmamembrane processes that wrap axons as a highly compacted multilayer membrane to insulate internodes.

Proteolipid protein (PLP) and $\mathrm{DM}_{20}$, a smaller isoform derived from alternative splicing, are the two major integral membrane proteins of CNS myelin (Stoffel et al., 1984). Their correct integration into the highly ordered membrane sheath is required for stabilizing the apposition of the adjacent extracellular membrane surfaces, ultrastructurally appearing as the interperiod dense line (IDL). Besides the naturally occurring mutants, e.g., jimpy (Nave et al., 1986) and rumpshaker (Schneider et al., 1992), two knock-out mouse models (Boison and Stoffel, 1994; Klugmann et al., 1997) have elucidated the structure-function relationship of this tetraspan membrane protein (Weimbs and Stoffel, 1992). In contrast to the point mutations (jimpy, rumpshaker), substantial myelination was observed in plp $-/-$ mice with a loss of the tight compaction at the IDL. The phenotype of the PLP-deficient mouse was inconspicuous, and a late onset of axon degeneration in the aging $p l p-/-$ mouse suggests a possible function of PLP and/or $\mathrm{DM}_{20}$ for axonal maintenance (Griffiths et al., 1998).

The family of myelin basic protein (MBP) isoproteins $(21.5,18.5$, 17 , and $14 \mathrm{kDa})$ results from alternative splicing. They comprise $30-40 \%$ of CNS and $5-15 \%$ of PNS myelin proteins (Lees and Brostoff, 1984). MBP plays a crucial role in the compaction of the opposing cytosolic surfaces of the plasma membrane processes, the main dense line (MDL) in electron microscopy (Omlin et al., 1982). The spontaneous shiverer mouse mutant, a "natural" knock-out, with deletion of exons 2-7 of the MBP gene (Roach et al., 1985; Molineaux et al., 1986) causes severe hypomyelination of CNS axons and leads to premature death within 3 months. No major

Received March 20, 2000; revised April 20, 2000; accepted April 26, 2000.

This work was supported by the Deutsche Forschungsgemeinschaft, SFB 243, the Bundesministerium für Wissenschaft, Forschung und Technologie, 01KS 9502, and the European Community contract BMH 4CT 96-0990. W.S. is responsible for the content of this publication. The mag $-/-$ mouse line was kindly supplied by Dr. B. Trapp, (Cleveland Clinic Foundation, Cleveland, $\mathrm{OH}$ ).

Correspondence should be addressed to Wilhelm Stoffel, Laboratory for Molecular Neuroscience, Institute of Biochemistry, Faculty of Medicine, University of Cologne, Joseph-Stelzmann-Strasse 52, D-50931 Cologne, Germany. E-mail: Wilhelm.Stoffel@ uni-koeln.de.

Copyright (C) 2000 Society for Neuroscience $0270-6474 / 00 / 205225-09 \$ 15.00 / 0$ morphological abnormalities are observed in the PNS (Rosenbluth, 1980).

A third minor, but important constituent of the CNS myelin membrane of differentiating oligodendrocytes and in PNS, is the myelin-associated glycoprotein (MAG). MAG appears as a component of the surface (Yim et al., 1995). Its main function is thought to mediate axon-glia contact during myelin assembly (Arquint et al., 1987; Trapp, 1990). MAG expression occurs in a time-specific manner and yields the L-MAG isoform predominantly expressed at an early and S-MAG at a later stage of myelination (Lai et al., 1987; Tropak et al., 1988; Inuzuka et al., 1991; Pedraza et al., 1991). Subtle ultrastructural abnormalities in CNS myelin of mag-/- mice were observed (Li et al., 1994; Montag et al., 1994). Axonal and myelin degeneration in the PNS but not in CNS was observed in older $m a g-/-$ mice (Fruttiger et al., 1995; Yin et al., 1998).

The characterization of the mouse models generated in this study together with the monogenetic mutants $[p l p-/-, m b p-/-$ (shiverer) and $m a g-/-]$ and the $p l p-/-m b p-/-$ double mutant provided extensive insight into the pivotal functions of the main myelin proteins for oligodendrocyte development, myelin formation, myelin structure, compaction, and maintenance of the myelin membrane, and particularly for axonal integrity.

\section{MATERIALS AND METHODS}

Animals. PLP-deficient mice ( $p l p-/-)$ (Boison and Stoffel, 1994) were crossed with MAG-deficient mice (mag-/-) (kindly supplied by Prof. Bruce Trapp, Cleveland Clinic Foundation, Cleveland, OH) (Li et al., 1994). The resulting F1 generation was intercrossed, and mice homozygous for the PLP/MAG deficiency ( $p l p-/-m a g-/-)$ were obtained. We generated the $\mathrm{PLP} / \mathrm{MBP} / \mathrm{MAG}$-deficient triple mutant mouse line (mag-/ $-p l p-/-m b p-/-)$ by crossing MAG-deficient mice (mag-/-) with PLP/ MBP-deficient animals from our transgenic breeding facility (Stoffel et al., 1997). The homozygous PLP/MBP/MAG-deficient triple mutant was obtained by intercrossing ( $p l p Y /-m b p-/-m a g+/-)$ male with $(p l p-/$ $-m a g-/-m b p+/-)$ female mice. MAG/PLP/MBP-deficient triple mutant animals are infertile. Shiverer mice $($ shi/shi $=m b p-/-)$ were selected from crossings of heterozygous animals $(\mathrm{mbp}+/-)$ (The Jackson Laboratory, Bar Harbor, ME).

Genotyping. Genotyping of the wild-type and mutant PLP allele was performed by hybridizing NcoI-digested genomic DNA with a genomic 700 bp BglII fragment that contains sequences of exon III and intron III of the PLP gene. A $3.6 \mathrm{~kb}$ fragment is indicative of the wild type and a $2.7 \mathrm{~kb}$ signal of the mutated allele. The deletion of the $m b p$ gene (exons II to VII) was verified by Southern blotting of Bam HI-digested genomic DNA with a 350 bp PCR fragment obtained with oligonucleotide primers hybridizing to a $5^{\prime}$ intron sequence upstream of the deleted exon II, 5'GAGGCCGCACATCAGCCCTGATTTTTGCTAAG3', and a corresponding 3'primer, 
5'CATGTATGAATGTGCATCTTGGGCAATCTATCT3', hybridizing to the sequence flanking the deletion downstream of exon VII. A $3.5 \mathrm{~kb}$ Bam HI fragment is diagnostic of the wild type and a $7 \mathrm{~kb}$ signal of the shiverer locus. The MAG genotype was examined by probing Bam HI/ HindIII restricted DNA with the $270 \mathrm{bp} E c o$ RI/AccI fragment of exon VII. A $7.7 \mathrm{~kb}$ band indicates the wild type and a $5.5 \mathrm{~kb}$ signal the targeted allele. $R N A$ analysis. RNA was prepared from total brain of 20 -d-old mice (Chomczynski and Sacchi, 1987).

Northern blot. RNA $(20 \mu \mathrm{g})$ was separated by $1 \%$ formaldehyde-agarose gel electrophoresis and blotted to nitrocellulose (GeneScreen Plus; NEN Life Science Products, Boston, MA) and hybridized with the following genomic and cDNA fragments of PLP, MBP, MAG, and GAPDH labeled with the random priming DNA-labeling kit (Boehringer Mannheim, Mannheim, Germany): a genomic 700 bp BglII fragment containing sequences of exon III and intron III of the PLP gene, a 266 bp PCR-fragment of MAG exon IX (5'primer: 5'GCAGTTGCCCCCATAATCCTTCTGGAGTCA3', 3'primer: 5'CTCTGGGTGCCATAGAGGTTCCTGGAGGTA3'), a 540 bp PCR cDNA fragment of MBP (5'primer: 5'CAAGAAGACCCCACAGCAGCTTCCGGAGGC3'，3'primer: 5'CAGGATTCG GGAAGGCTGAGCGGGGAGGGC3'), and a 550 bp HindIII/XbaI cDNA fragment of human liver glyceraldehyde 3-phosphodehydrogenase (GAPDH). Fragments were purified using the Quiaex gel extraction kit (Qiagen, Chatsworth, CA).

Quantitative RT-PCR. Five micrograms of RNA treated with RNase-free DNase were subjected to the first strand synthesis (SuperscriptII; Life Technologies $\mathrm{GmbH}$, Karlsruhe, Germany). We used 1/20 of the reaction for each PCR in $30 \mu \mathrm{l}$ in the presence of $0.1 \mu \mathrm{l}$ of ${ }^{32} \mathrm{P}$-dCTP. Samples were taken after $15,17,19$, and 21 cycles and separated on $6 \%$ polyacrylamide gels. Gels were dried and analyzed with a PhosphorImager (Molecular Dynamics, Sunnyvale, CA) using the Imagequant software (Molecular Dynamics). The following oligonucleotide primers were used: MAG: 5': 5'TGCTCACCAG CATCCTCACG3'， 3': 5'AGCAGCCTCCTCTCAGATCC3'; PLP: 5': 5'CAAGCTCATTCTTTGGAGCG3', 3': 5'CAATCATGAAGGTGAGC AGG3';MBP:5':5'TACCTGGCCACAGCAAGTAC3', 3':5'GTCACAATG TTCTTGAAG3'; GAPDH: 5': 5'GAGCTGAACGGGAAGCTCAC3', 3'; 5'CACCACCCTGTTGCTGTAGC3'; OMgp: 5': 5'GCAGCAGCTGCA ACTCTAAC3', 3': 5'GAAGCATTTACTTTCCAAGCA3'; MOG: 5': 5' CCAAGAGGAGGCAGCAATGG3', 3': 5'GTTGTAGCAGATGATCAA GG3'; NCAM120: 5': 5'CCTGAAGAGCATCCAGTACA3', 3': 5'ATGA ATTCCAAGGACTCCTG3'; NCAM140: 5': 5'CCATCAGACACTATCT GGTC3'， 3': 5'TCAGGAAGTAGCAGGTGATG3'; CGT: 5': 5'GAA ATTCACAAGGATCAACC3', 3': 5'GTCCATTAACTGTGCTATGC3'.

Isolation of myelin and protein analysis. Myelin of total brain of 28-d-old mice was purified by sucrose gradient centrifugation. One brain was homogenized in $10 \mathrm{ml}$ of $0.32 \mathrm{M}$ sucrose. The suspension was layered on top of $20 \mathrm{ml}$ of $0.85 \mathrm{M}$ sucrose and centrifuged at $10,000 \times g$ for $20 \mathrm{~min}$. The myelin-containing interphase was collected with a bent Pasteur pipette, diluted with three volumes of water, sedimented at $10,000 \times g$ for 30 min, and washed twice with water (Norton and Poduslo, 1973). Aliquots were separated on $10-15 \%$ SDS-PAGE. Individual proteins were visualized by Western blot analysis (Towbin et al., 1979) with SuperSignal Substrate (Pierce, Rockford, IL), using anti-MBP antibodies (Boehringer Mannheim) and polyclonal anti-PLP (whole protein) and anti-MAG $\left(\mathrm{Gln}^{376}-\mathrm{Tyr}^{390}\right)$ antibodies generated in our laboratory.

PNS proteins were isolated by homogenization and sonication of sciatic nerves in $200 \mu \mathrm{l}$ of BUST buffer $(50 \mathrm{~mm}$ Tris- $\mathrm{HCl}, \mathrm{pH} 7.4,8 \mathrm{M}$ urea, $2 \%$ $\beta$-mercaptoethanol, and $0.5 \%$ SDS). After centrifugation at $5 \times 10^{5} \mathrm{rpm}$ for $20 \mathrm{~min}$ at $25^{\circ} \mathrm{C}$ the supernatant was used for protein analysis.

Lipid analysis. Lipids were extracted from mouse brain, sciatic, and pectineus nerves as described before (Bligh and Dyer, 1959). The extracted lipids were dissolved in $300 \mu \mathrm{l}$ of chloroform/methanol (2:1), lipids from mbp-deficient mice in $30 \mu \mathrm{l}$ chloroform/methanol (2:1). Lipids were separated by high-performance thin-layer chromatography (HPTLC) on silica gel-precoated plates (HPTLC 60; $10 \times 10 \mathrm{~cm}$ plates; Merck, Darmstadt, Germany) in the solvent system chloroform/methanol/water $(65: 25: 4)$. Lipid bands were visualized by charring with $50 \% \mathrm{H}_{2} \mathrm{SO}_{4}$ at $120^{\circ} \mathrm{C}$ for 15 min and confirmed by standards. Gangliosides of purified myelin were separated in the solvent system chloroform/methanol/water/ammonia (60: 35:6:2), stained with orcin-reagent at $95^{\circ} \mathrm{C}$ for $15 \mathrm{~min}$. For semiquantitative lipid analysis, HPTLC plates were scanned, and lipid bands were integrated with a PhosphorImager. Mean values and their SEs were estimated from three independent experiments.

Light and electron microscopy. Anesthetized mice were perf used with $6 \%$ glutaraldehyde for light and electron microscopy. The optic nerve and cervical segments of the spinal cord were isolated, post-fixed in $1 \%$ phosphate-buffered $\mathrm{OsO}_{4}$ in $0.1 \mathrm{M}$ sucrose, and embedded in Epon 812. The semithin sections were stained with toluidine/pyronin. Ultrathin crosssections of optic nerve and spinal cord were contrasted with uranylacetate and lead citrate and examined as previously described (Bussow, 1978).

Conduction velocity measurement. Nerve conduction was measured by proximal stimulation of the sciatic nerve at the knee and distal close to the hip, using a Medelec electromyograph, model MS92.

Behavioral testing (Wallace et al., 1980). The following tests were performed with eight mice of each genotype except for the shiverer mice with six and the PLP/MBP/MAG-deficient mice with seven mice. The behavior tests, which were performed during a 2 month period, were started with mice of the following age: controls: CD1 10 weeks; C57/B16 12 weeks;

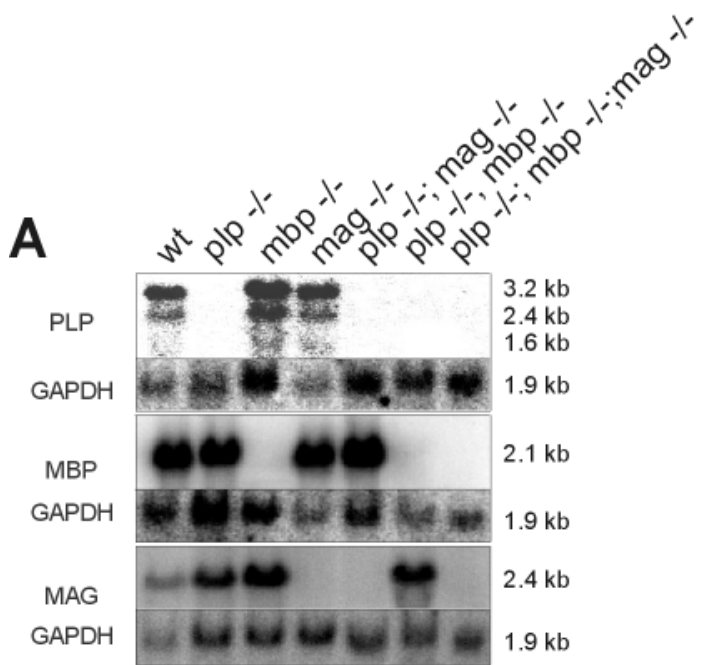

B

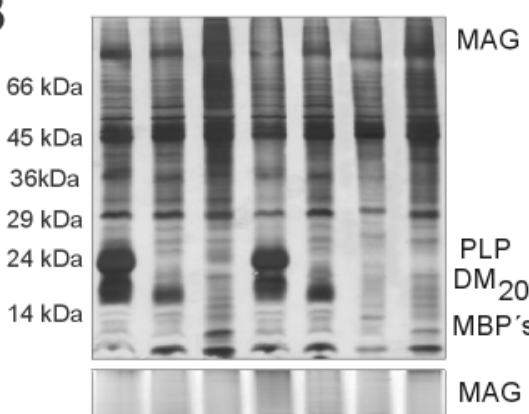

$66 \mathrm{kDa}$

$45 \mathrm{kDa}$

$36 \mathrm{kDa}$

29 kDa

24 kDa

14 kDa
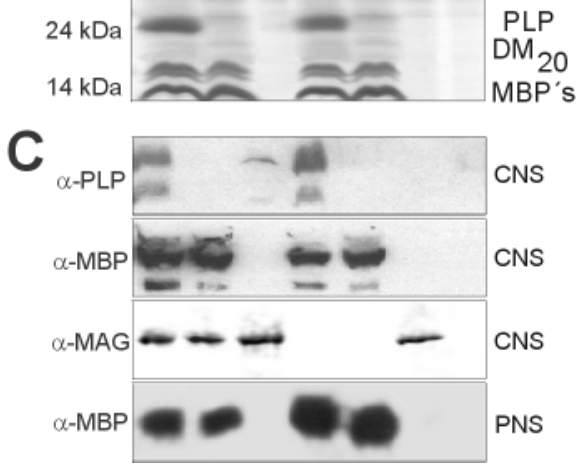

Figure 1. $A$, Northern blot analysis; $B$, SDS-PAGE analysis [silver (top) and Coomassie staining (bottom)]; $C$, Western blot analysis of $w t$ and six mutant mouse lines.

(mag-/-) 20 weeks; ( plp-/-) 10 weeks; (mbp-/-) 6-8 weeks; (mag-/ $-p l p-/-) 10$ weeks; ( 1 lp-/-mbp-/-) 10 weeks; (mag-/-plp-/ $-m b p-/-) 8$ weeks.

Morris water maze (Morris, 1984). Water mazes took place in a black circular polyethylene tub $(69 \mathrm{~cm}$ diameter, $22 \mathrm{~cm}$ high) with an escape platform, a black cylinder $(7.5 \mathrm{~cm}$ diameter), submerged $0.5 \mathrm{~cm}$ below the surface of the water, in a constant position). Water temperature was $21^{\circ} \mathrm{C}$. The animal was set into the water at a randomly determined quadrant. A trial was finished when the mouse had reached the escape platform or at the set time of $90 \mathrm{sec}$. Animals were allowed to recover for $30 \mathrm{sec}$ on the platform before another trial was started. Each mouse was tested in four subsequent trials over $5 \mathrm{~d}$. Escape latency, number of squares crossed, and swimming speed were video-recorded. At the fifth day an additional $30 \mathrm{sec}$ trial was performed with the escape platform being removed (probe trial). The number of crossings of the previous position of the platform was counted. The trials were registered and processed with the software MOR 005 (Tropon-Werke, Cologne, Germany) and statistically evaluated using 
Table 1. Quantitative RT-PCR analysis

\begin{tabular}{|c|c|c|c|c|c|c|c|c|}
\hline Genotype & PLP & MBP & MAG & MOG & OMgp & CGT & N-CAM140 & N-CAM120 \\
\hline wt & 1 & 1 & 1 & 1 & 1 & 1 & 1 & 1 \\
\hline plp $-/-$ & - & $1.2 \pm 0.2$ & $1.1 \pm 0.4$ & $0.8 \pm 0.5$ & $1.1 \pm 0.3$ & $1.3 \pm 0.4$ & $1.3 \pm 0.2$ & $1.1 \pm 0.4$ \\
\hline $\mathrm{mbp}-/-$ & $1.4 \pm 0.5$ & - & $\mathbf{3 . 4} \pm 0.7$ & $1.3 \pm 0.4$ & $0.9 \pm 0.2$ & $1.1 \pm 0.2$ & $1.4 \pm 0.4$ & $1.1 \pm 0.1$ \\
\hline $\operatorname{mag}-1-$ & $1.3 \pm 0.4$ & $1.5 \pm 0.3$ & - & $0.8 \pm 0.2$ & $0.9 \pm 0.5$ & $0.8 \pm 0.5$ & $1.6 \pm 0.7$ & $0.7 \pm 0.3$ \\
\hline $\mathrm{plp}-/-\operatorname{mag}-/-$ & - & $0.9 \pm 0.4$ & - & $1 \pm 0.4$ & $1.1 \pm 0.2$ & $0.8 \pm 0.4$ & $0.8 \pm 0.5$ & $1.2 \pm 0.3$ \\
\hline $\mathrm{plp}-/-\mathrm{mbp}-/-$ & - & - & $2.7 \pm 0.4$ & $1.4 \pm 0.3$ & $1.2 \pm 0.4$ & $1.2 \pm 0.5$ & $1.3 \pm 0.5$ & $1.2 \pm 0.5$ \\
\hline $\mathrm{plp}-/-\mathrm{mbp}-/-\mathrm{mag}-/-$ & - & - & - & $0.9 \pm 0.4$ & $0.7 \pm 0.3$ & $1.1 \pm 0.3$ & $0.7 \pm 0.3$ & $1.5 \pm 0.2$ \\
\hline
\end{tabular}

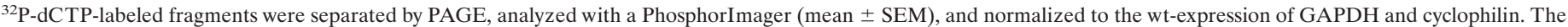

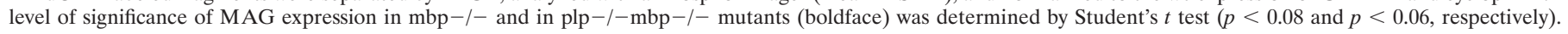

the ANOVA software (Tropon-Werke) (Morris, 1984; Klapdor and van der Staay, 1996; Klapdor and van der Staay, 1998).

Open field. Animals were placed in the middle of a box $(60 \times 60 \mathrm{~cm})$, the bottom of which was subdivided into $10 \times 10 \mathrm{~cm}$ squares. Square crossings, rearing, grooming, and the location of the mouse (middle, wall, corner) were registered under video control over periods of $15 \mathrm{~min}$. Mice were adapted in a quiet room under red light illumination. Data were processed with the software OBSERVE 004 (Tropon-Werke) and statistically evaluated with ANOVA software.

Rotarod test (Wallace et al., 1980). Animals were placed on a resting rod (diameter $3 \mathrm{~cm}$ ) $20 \mathrm{~cm}$ above the ground for $1 \mathrm{~min}$, and the rotation started at $0.4 \mathrm{rpm}$ and doubled every $60 \mathrm{sec}$. The time interval during that the mice stayed on the rod was measured. The test was repeated three times a day over a period of $5 \mathrm{~d}$. In the final task on day 5 , the mouse was placed on the rod constantly rotating at 4 or $8 \mathrm{rpm}$, respectively. The drop off frequency within $90 \mathrm{sec}$ was measured (Kuhn et al., 1995).

Descending a vertical pole (Wallace et al., 1980). A pole wrapped with cord ( $2 \mathrm{~cm}$ diameter, $80 \mathrm{~cm}$ length) and bordered at its upper end by a plate was held in a horizontal position. The mouse was placed with its forelimbs pointing to the platform. After turning the pole into a vertical position the time needed to turn around and required to descend and reach the floor was measured. Also the drop offs, sliding down and climbing up again, was scored. The procedure was repeated three times. A cutoff of $300 \mathrm{sec}$ was chosen.

Horizontal bridge (Wallace et al., 1980). Mice were placed in the middle of a horizontal wooden bar $(2 \times 2 \mathrm{~cm}, 60 \mathrm{~cm}$ length $)$ bridging two platforms $(50 \mathrm{~cm}$ above the floor). The time to reach the platform, dropping off the bridge, and the time until the drop off occurs were measured.

Horizontal wire (Wallace et al., 1980). The mouse was placed with its forelimbs to the middle of a horizontal metal wire $(2 \mathrm{~mm}$ diameter, $60 \mathrm{~cm}$ length) connecting two platforms $(5 \times 2 \mathrm{~cm} ; 50 \mathrm{~cm}$ above the floor). The time needed to reach one of the platforms, dropping off the wire, and the time until the drop off occurred were measured. A cutoff time of $180 \mathrm{sec}$ was selected.

\section{RESULTS}

We generated two mutant mouse lines, the $p l p-/-$ mag $-/-$ double mutant by crossing the $p l p-/-$ into the mag-/- locus and a homozygous triple mutant $p l p-/-m b p-/-m a g-/-$ lacking PLP, $\mathrm{MAG}$, and MBP by crossing the $m b p+/-$ genotype into the homozygous plp $-/-$ mag $-/-$ double mutant. For comparison we included the monogenic mutants, the $p l p-/-m b p-/-$ double mutant, and the wild type in the biochemical, morphological, and physiological analyses of six mutant genotypes: plp-/-; $m b p-/-$ (shi/shi); mag-/-; plp-/-mag-/-; plp-/-mbp-/-, and plp-/ $-m b p-/-m a g-/-$. Their genotypes were verified by Southern blot analysis, which revealed the restriction fragments length polymorphism diagnostic for the respective targeted gene loci (data not shown). The missing mRNAs in Northern blot analysis (Fig. 1A), together with the absence of PLP, MBP, and MAG in SDS-PAGE and Western blot analysis proved that we had generated the two homozygous mouse lines (Fig. $1 B, C$ ). Sensitive protein detection methods (silver staining) and extensive Western blot analysis using polyclonal PLP and MAG antibodies and a monoclonal MBP antibody failed to detect any of the gene products in the respective mutants, including hypothetical immunoreactive PLP-related polypeptides (Fig. 1B) (Boison and Stoffel, 1994; Klugmann et al., 1997). Western blot analysis of sciatic nerve using the MBP-specific antibody revealed that $\mathrm{MBP}$ is selectively upregulated twofold in peripheral nerves of $p l p-/-m a g-/-$ double mutant mice as previously reported for mag-/- mice (Fig. 1B) (Li et al., 1994).
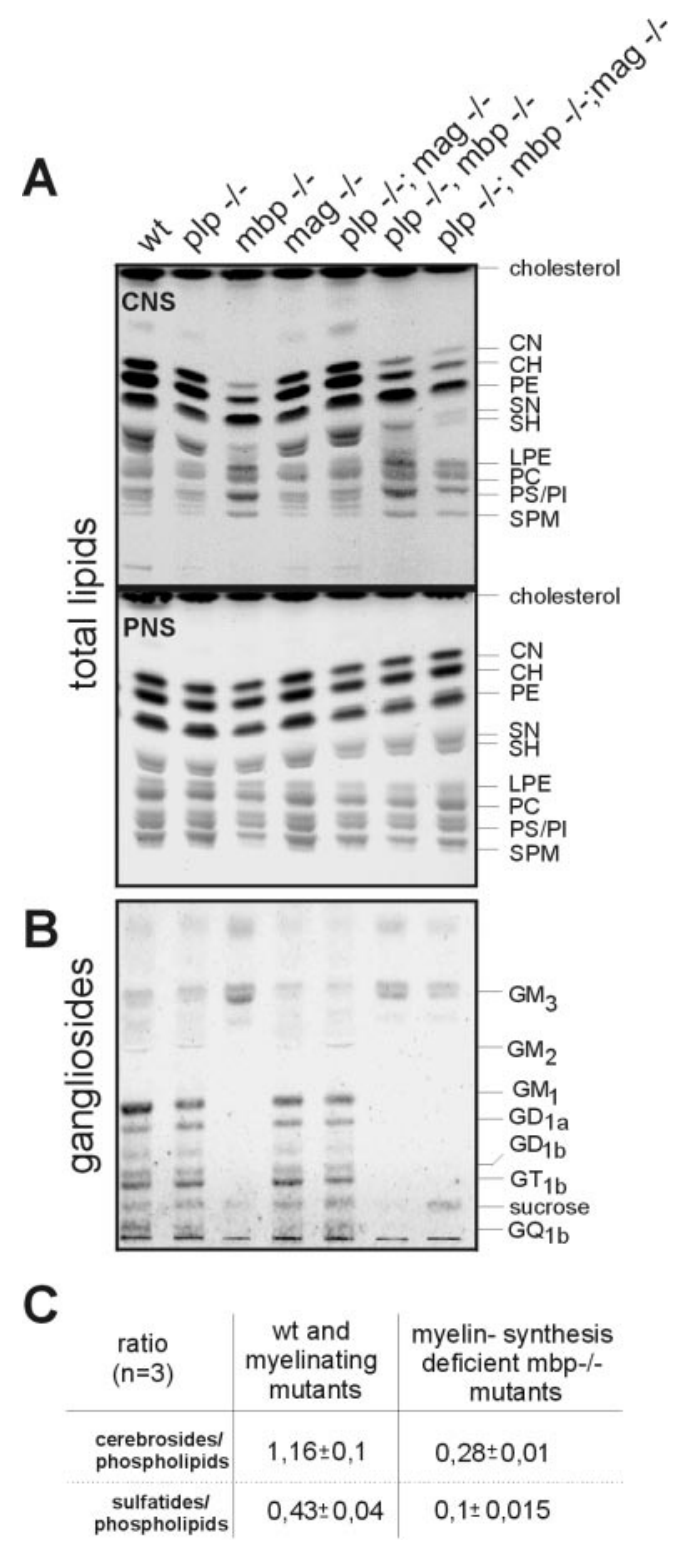

Figure 2. Analysis of total lipids of purified myelin and sciatic nerve. Six aliquots of brain extracts of mice carrying the shiverer genotype and one aliquot of the other genotypes were separated by HPTLC. $A$, Total lipids, solvent system: chloroform/methanol/water 65:25:4. $C N$, Normal fatty acidsubstituted GalC; $\mathrm{CH}, \alpha$-hydroxy fatty acid-substituted GalC; $P E$, phosphatidylethanolamine; $S N$, normal fatty acid-substituted sGalC; $S H$, $\alpha$-hydroxy fatty acid-substituted sGalC; $L P E$, lysophosphatidylethanolamine; $P C$, phosphatidylcholine; $P S$, phosphatidylserine; $P I$, phosphatidylinositol; SPM, sphingomyelin. B, Gangliosides of purified myelin, solvent system: chloroform/methanol/water/ammonia 60:35:6:2, were identified by comparison with HPLC purified standards. $C$, Semiquantitative lipid analysis, quantification with a PhosphorImager (mean \pm SEM). 
Table 2. Behavioral test: Morris water maze escape task

\begin{tabular}{|c|c|c|c|c|c|c|c|c|c|c|c|c|c|c|c|}
\hline & \multicolumn{3}{|l|}{ wt C57/bl6 } & \multicolumn{3}{|l|}{ wt CD1 } & \multicolumn{3}{|l|}{ plp-/- } & \multicolumn{3}{|l|}{ mag-/- } & \multicolumn{3}{|c|}{ plp $-/-$, mag $-/-$} \\
\hline & day 1 & day 3 & day 5 & day 1 & day 3 & day 5 & day 1 & day 3 & day 5 & day 1 & day 3 & day 5 & day 1 & day 3 & day 5 \\
\hline $\begin{array}{c}\text { Mean escape la- } \\
\text { tency (sec) }\end{array}$ & $66.1 \pm 10.2$ & $13.1 \pm 2.1$ & $8.4 \pm 1.5$ & $55.1 \pm 10.0$ & $13.8 \pm 2.8$ & $10.3 \pm 1.4$ & $53.1 \pm 3.5$ & $21.0 \pm 5.9$ & $11.1 \pm 2.6$ & $72.0 \pm 7.9$ & $30.1 \pm 9.6$ & $6.5 \pm 0.6$ & $90.0 \pm 0$ & $87.5 \pm 2.5$ & $86.3 \pm 3.7$ \\
\hline $\begin{array}{l}\text { Mean swimming } \\
\text { speed (crossec }\end{array}$ & & & & & & & & & & & & & & & \\
\hline
\end{tabular}

Results in Tables $2-6$ represent mean values ( \pm SEM).

\section{Phenotypes of myelin mutants}

Plp $-/-$ and mag-/- single null allelic mutants had no obvious phenotype. However, the double mutant plp-/-mag-/- developed a tremor of the hindlimbs around postnatal week 4 . The initial tremor constantly progressed to dragging and jerky-like movement of the hindlimbs with increasing age. No convulsions were observed. Despite these neurological symptoms, the $p l p-/-$ mag $-/-$ double mutant had a normal life span (see Table 7). The motor behavior of triple mutant mice $(p l p-/-m b p-/-m a g-/-)$ differed from that of the $p l p-/-m b p-/-$ double mutant by the combination of the shiverer trait with its high-frequency tremor and the PLP/MAG deficiency with its impairment described above. Seizures and convulsions did not occur until 3 months after birth but then with a high frequency. Their life span is 7-9 months, significantly longer than that of the MBP-deficient (shiverer) mouse of $\sim 3$ months (see Table 7) (Chernoff, 1981).

\section{Transcriptional regulation of gene expression in the mouse mutants}

We studied the complex gene expression pattern of oligodendrocytes in the single, double, and triple mutants first on the transcriptional level by Northern blot analysis (Fig. 1 $A$ ). Searching for compensatory mechanisms, we expanded this study to genes possibly involved in this mechanism by quantitative RT-PCR of RNA of additional oligodendrocyte-specific proteins (MOG, OMGP, CGT) and two forms of the neural cell adhesion molecule N-CAM (140 and $120 \mathrm{kDa}$ isoforms). Total RNA from p20 mouse brains and the respective oligonucleotide primers yielded PCR fragments of the expected size. Two housekeeping enzymes, GAPDH and cyclophilin, were included for comparison (Table 1).

The only significant difference in the expression pattern between the mutants and wt was a twofold to threefold overexpression of MAG in shiverer - and $p l p-/-m b p-/-$ double mutant mice (Table 1). Further analysis of the transcripts of the MAG gene revealed that the overexpression of MAG is predominantly contributed by the smaller isoform, S-MAG, in the mutant CNS (data not shown). This overexpression was restricted to the mRNA but not to MAG protein synthesis as shown by Western blot analysis (Fig. 1C).

\section{Deficiencies of CNS-myelin proteins are associated with alterations in myelin membrane lipid synthesis}

To explore the differences in myelination the total amount of myelin, isolated from brain homogenates of 6-week-old mutant and $w t$ mice by discontinuous sucrose gradient centrifugation, was determined (Norton and Poduslo, 1973). The yield of total myelin from brains of $w t, p l p-/-$, mag-/-, and plp-/-mag-/- double mutant mice was approximately identical (wt: $18.1 \pm 2.4 \mathrm{mg}$; plp-/-: $18.6 \pm 5.3 \mathrm{mg}$; mag-/-: $16.7 \pm 0.9 \mathrm{mg} ;$ plp-/-mag-/-: $18.3 \pm 2.9 \mathrm{mg})$. However, the amount of myelin obtained from brains of the remaining mutants was strikingly low ( $\mathrm{mbp}-/-: 0.7 \pm$ $0.3 \mathrm{mg} ;$ plp-/-mbp-/-: $0.7 \pm 0.5 \mathrm{mg}$; $p l p-/-m b p-/-$ mag-/-: $0.6 \pm 0.4 \mathrm{mg}$ ). Although the amount of myelin from brains of mice carrying the shiverer genotype were similar, oligodendrocytes of the double mutant $p l p-/-m b p-/-$ and the triple mutant $p l p-/$ $-m b p-/-m a g-/-$ mice wrap a significant number of larger diam- eter axons with a "pseudomyelin" sheath (see Fig. 4A, electron microscopy).

In view of the ultrastructural finding of "pseudomyelin" membranes around larger diameter axons in the $p l p-1-m b p-/-$ and the triple mutant CNS (Fig. 3) and the minute amount of proteins isolated from their myelin, we studied the lipid composition of purified myelin fractions of the different genotypes, not of total brain. Previous reports focused on the lipids of whole brain of shiverer mouse (Norton and Poduslo, 1973; Bird et al., 1978; Cammer et al., 1984; Iwamori et al., 1985). We analyzed total lipids from purified CNS myelin, pectineus, and sciatic nerves by HPTLC. Whereas the lipid composition of CNS myelin of $p l p-/-$, mag-/-, and $p l p-/-$ mag $-/-$ mutants was unaffected, mutants carrying the MBP deletion showed significant differences in the amounts of total phospholipids and myelin-specific lipids. In CNS myelin of all mutants carrying the MBP deletion, the ratio of the oligodendrocyte-specific lipids, galactocerebrosides, and sulfatides to phospholipids was reduced fourfold. This ratio remained unchanged in the other mutants like in control mice (Fig. 2A,C). Cerebrosides and sulfatides were both considerably reduced in the CNS of MBP-deficient mice, although the gene expression of the key enzyme of galactocerebroside and sulfatide biosynthesis, the UDP-galactose:ceramide galactosyltransferase (CGT) (EC 2.4.1.45) (Schulte and Stoffel, 1993), was not altered (Table 1).

The lipid analysis of CNS myelin of the mutants containing the shiverer trait furthermore revealed that the sphingomyelin fraction consisted of only one species, stearoyl-sphingomyelin. This structure was ascertained by MALDI-TOF MS (matrix-assisted laser desorption/ionization time of flight mass spectroscopy) (data not shown).

Gangliosides of CNS myelin of mice with the $m b p-/-$ mutation were distinctly decreased. Complex higher gangliosides $\left(\mathrm{GM}_{1}\right.$, $\mathrm{GD}_{1 \mathrm{a}}, \mathrm{GD}_{1 \mathrm{~b}}, \mathrm{GT}_{1 \mathrm{~b}}$, and $\mathrm{GQ}_{1 \mathrm{~b}}$ ) were almost absent, and only $\mathrm{GM}_{3}$ were present as main ganglioside species (Fig. 2B). Membrane lipids in the myelin sheaths of peripheral nerves were unaffected in the different genotypes.

\section{Behavioral characteristics of the mutants}

To further characterize each mutant, we studied the cognitive and motor-coordinative capacities in behavioral tests. The two double and the triple mutants differ clearly from each other by the degree of impaired neuromotor coordination. Mouse mutants carrying the shiverer trait ( $m b p-/-; p l p-/-m b p-/-; p l p-/-m b p-/-m a g-/-)$ were excluded from the Morris water maze escape task (Morris, 1984 ) because they were unable to swim over the period of time required for the task. $P l p-/-m a g-/-$ double mutant mice were compared with their respective monogenic mutants and two wildtype strains (C57/B16, inbred; CD1, outbred). Whereas $p l p-/-$ and mag-/- mice showed a normal swimming speed and learning behavior and were indistinguishable from $w t$ mice, none of the plp $-/-$ mag- $-1-$ mutants was able to locate the platform and acquire spatial discrimination in the water maze. Because of their jerky-like movement of the hindlimbs they were not able to swim, but drifted on the water surface. That explains their distinctly reduced swimming speed compared to $w t$ mice (Table 2). None of 
Table 3. Behavioral test: open field

\begin{tabular}{lccc} 
Genotype & Locomotion & Grooming & Rearing \\
\hline wt C57/Bl6 & $515.0 \pm 47.6$ & $10.0 \pm 2.0$ & $92.5 \pm 12.8$ \\
wt CD1 & $511.3 \pm 45.4$ & $9.9 \pm 2.4$ & $90.3 \pm 10.4$ \\
plp-/- & $578.5 \pm 36.9$ & $8.0 \pm 2.2$ & $57.2 \pm 10.2$ \\
mbp-/- & $43.3 \pm 5.0$ & $4.0 \pm 0.8$ & $9.3 \pm 1.7$ \\
mag-/- & $253.1 \pm 79.7$ & $2.5 \pm 0.9$ & $20.3 \pm 10.0$ \\
plp-/-mag-/- & $318.4 \pm 78.6$ & $7.6 \pm 2.3$ & $59.3 \pm 15.5$ \\
plp-/-mbp-/- & $323.6 \pm 34.9$ & $4.9 \pm 1.1$ & $43.9 \pm 7.3$ \\
plp-/-mbp-/-mag-/- & $41.6 \pm 12.7$ & $3.6 \pm 1.4$ & $10.4 \pm 4.3$ \\
\hline
\end{tabular}

Table 4. Behavioral test: horizontal bridge

\begin{tabular}{lccc} 
Genotype & $\begin{array}{l}\% \text { of mice } \\
\text { reaching a } \\
\text { platform }\end{array}$ & $\begin{array}{l}\text { nr of mice } \\
\text { dropping } \\
\text { off }\end{array}$ & $\begin{array}{l}\text { Latency to reach } \\
\text { a platform (sec) }\end{array}$ \\
\hline wt C57/Bl6 & 100 & 0 & $9.9 \pm 9.73$ \\
wt CD1 & 100 & 0 & $9.4 \pm 1.9$ \\
plp-/- & 95.8 & 0 & $8.9 \pm 1.2$ \\
mbp-/- & 95.8 & 1 & $20.3 \pm 2.3$ \\
mag-/- & 45.8 & 2 & $65.3 \pm 19.7$ \\
plp-/-mag-/- & 62.5 & 7 & $32.0 \pm 11.4$ \\
plp-/-mbp-/- & 79.2 & 0 & $74.6 \pm 21.1$ \\
plp-/-mbp-/-mag-/- & 16.7 & 10 & $92.5 \pm 18.3$ \\
\hline
\end{tabular}

these mice ever entered the previous training quadrant during the probe trial.

Locomotor activity of the mutants was measured in the open field test (Table 3). As expected, shiverer - and triple mutant mice showed a dramatic decrease in activity compared to $p l p-/-$ and $w t$ mice. The locomotor activity of $m a g-/-$ and the two double mutants, $p l p-/-m b p-/-$ and $p l p-/-$ mag $-/-$, ranged in between these two groups.

To determine the motor and posture pattern, the following tasks were applied to challenge mutant mice: clinging to a horizontal wire (Table 6), moving on a horizontal bridge (Table 4), and descending from a vertical pole (data not shown). The most striking result was that $m a g-/-$ mice, $p l p-/-m a g-/-$ double and triple mutants did not reach the platform when starting from the middle of the horizontal wire or bridge. In these two tasks a clear gradation between mutants became apparent: whereas the mag-/mutant on the average dropped off twice during the defined "cutoff" time, plp $-/-$ mag $-/-$ double mutant mice fell from the bridge seven times, and only half of tested triple mutant mice were able to remain on the bridge. In the vertical pole task the double and triple mutant mice slid down the pole instead of climbing down in a coordinate fashion like wild-type mice (data not shown).
Finally, the learning behavior and skill of the mutants was scored on a rotating rod on 5 subsequent days (Kuhn et al., 1995). All mice, including the heavily affected animals with the shiverer trait, learned to stay on the rod rotating with increasing speed and improved their skill. The time mice remained on the rod depended significantly on the degree of impairment of their motor coordination. This is illustrated by the record of cumulative falls from the rotating rod (Table 5). The performance of $p l p-/-$ mice was comparable to $w t$ mice in this task, whereas mag $-/-$ mice exhibited small but significant differences compared to $w t$ mice. Triple mutant mice are the most affected genotype in this task. The performance of shiverer and double mutant mice $p l p-/-m b p-/-$ and plp-/-mag-/- can be classified as intermediate between these genotypes, $m a g-/-$ and the $p l p-/-m b p-/-m a g-/-$.

\section{Conduction velocity of peripheral nerves of the mutant mice is unchanged}

The impact of the protein deficiency on the conduction velocity of peripheral nerves was measured by electromyography. Proximal stimulation of the sciatic nerve at the knee and distal close to the hip was applied. No significant differences in conduction velocities of peripheral nerves of $w t$ and mutant mice, 4-5 months of age, were observed. They range between 26.5 and $32 \mathrm{~m} / \mathrm{sec}$.

\section{Morphology of mutant CNS myelin structures}

The genetic, biochemical, physiological, and behavioral traits of each phenotype were complemented by extensive morphological studies of CNS myelin of the different mutants by electron microscopy, which also depicts schematically these structural changes of the myelin membrane (Fig. 3). The CNS myelin sheath of mag-/mice showed regular MDLs and IDLs with some subtle morphological abnormalities, e.g., doubled myelin sheaths, shortened periaxonal collar, and the appearance of longitudinal channels within compacted myelin (Li et al., 1994; Montag et al., 1994). In agreement with a previous report, we observed no reduced periaxonal spacing (Montag et al., 1994).

Another compaction type of the myelin membrane is dictated by the lack of the integral membrane protein PLP. Myelin membrane stacks of $p l p-/-$ and $p l p-/-$ mag $-/-$ mice are decompacted in the absence of PLP and $\mathrm{DM}_{20}$ at the IDL (Boison and Stoffel, 1994; Montag et al., 1994; Boison et al., 1995). In addition, condensed areas with main and intraperiod dense lines that are indistinguishable in electron density were observed (Fig. 3). In plp-/-mag-/double mutant mice the morphological abnormalities of the $m a g-/-$ and $p l p-/-$ single mutants are accumulated. Most strikingly we observed in the plp-/-mag-/- double mutant an early onset of axon degeneration around postnatal day 40 (P40), which starts in the $p l p-/-$ mouse only at later stages of life (Griffiths et al., 1998). An increased number of degenerated axons of the optic nerve and the ventral funiculus of the spinal cord is seen in light microscopy of optic nerves of 40-d-old mice, and a massive axonal degeneration is apparent in P120 mice (Fig. 4).

The three genotypes that we included in this study, the shiverer-, the $p l p-/-m b p-/-$ double, and $p l p-/-m b p-/-m a g-/-$ triple

Table 5. Behavioral test: rotarod

Increasing speed: time remaining on rod

Genotype

wt C57/B16

wt CD1

plp-/-

$\mathrm{mbp}-1-$

mag $-1-$

plp $-/-$ mag $-/-$

$\mathrm{plp}-/-\mathrm{mbp}-/-$

plp $-/-\mathrm{mbp}-/-\mathrm{mag}-/-$

$\begin{aligned} \text { day } 1 & \\ 169.4 & \pm 56.7 \\ 289.3 & \pm 41.0 \\ 186.1 & \pm 59.4 \\ 17.8 & \pm 11.7 \\ 178.2 & \pm 33.1 \\ 22.5 & \pm 9.8 \\ 11.3 & \pm 4.6 \\ 40 & \pm 13.5\end{aligned}$

Constant speed: cumulative falls in $90 \mathrm{sec}$

\begin{tabular}{lr}
\hline \multicolumn{1}{l}{ rpm } & \multicolumn{1}{c}{$8 \mathrm{rpm}$} \\
\hline 0 & \multicolumn{1}{l}{0} \\
0 & $0.4 \pm 0.2$ \\
0 & $1 \pm 0.7$ \\
$7.7 \pm 1.4$ & $10.2 \pm 0.9$ \\
$1 \pm 0.6$ & $4.4 \pm 1.9$ \\
$3.9 \pm 1.1$ & $12.9 \pm 1.4$ \\
$7.8 \pm 1.7$ & $15.3 \pm 2.6$ \\
$12.1 \pm 2.3$ & $18.4 \pm 0.8$ \\
\hline
\end{tabular}


Table 6. Behavioral test: horizontal wire

\begin{tabular}{lll} 
Genotype & $\begin{array}{l}\% \text { of mice clinging } \\
\text { the wire }\end{array}$ & $\begin{array}{l}\text { nr of mice reaching } \\
\text { a platform }\end{array}$ \\
\hline wt C57/B16 & 87.5 & 3 \\
wt CD1 & 66.7 & 4 \\
plp-/- & 70.8 & 0 \\
mbp-/- & 91.7 & 5 \\
mag-/- & 76.2 & 0 \\
plp-/-mag-/- & 20.8 & 0 \\
plp-/-mbp-/- & 66.7 & 3 \\
plp-/-mbp-/-mag-/- & 66.7 & 0 \\
\hline
\end{tabular}

mutant mice show another type of dysmorphic myelin structure. Hypomyelination of the CNS is the dominant leading symptom in the shiverer mouse (Chernoff, 1981) and is combined with a remarkable increase of oligodendrocytes in the spinal cord (Nagara et al., 1983) accompanied by the appearance of numerous SchmidtLantermann incisures in the PNS (Gould et al., 1995). The shiverer genotype confers this phenotype to the two other mutants. However, unlike oligodendrocytes of the shiverer mutant that are nearly unable to enwrap CNS axons, oligodendrocytes of the $p l p-/$ $-m b p-/-$ double and the $p l p-/-m b p-/-m a g-/-$ triple mutants spirally surround large-diameter axons as loosely compacted myelin consisting of only few lamellae (Fig. $4 A$ ). They adhere tightly at their extracytosolic surfaces forming a distinct electron-dense line of a myelin-like structure with a compacted IDL. The complete surrounding of an axon by alternately compacted myelin in the $p l p-/-m b p-/-$ double and triple mutants is obviously sufficient to facilitate a normal life span in the $p l p-/-m b p-/-$ and an extended lifespan in the $p l p-/-m b p-/-m a g-/-$ mutant under laboratory conditions. Addition of the mag-/- genotype to the double mutant causes the early onset of axonal degenerations in the triple mutant mouse, which shortens its life span (Table 7).

\section{DISCUSSION}

Gene targeting by homologous recombination of mutant mouse genes that replace the wt genes has proven to be a useful tool in the functional analysis of structural proteins of CNS and PNS myelin. Here we describe the generation and characterization of two new mutant mouse lines, a plp-/-mag-/- double mutant and a homozygous triple mutant lacking PLP, MBP, and MAG ( $p l p-/$ $-m b p-/-m a g-/-)$. Surprisingly, $p l p-/-m a g-/-$ double mu- tants, in contrast to their respective single mutants, showed severe neurological symptoms with increasing age.

The triple mutant, like the other homozygous $p l p-/-m b p-/-$ double mutant, bears a strong resemblance to shiverer mice. However, the tremor contributed by the shiverer trait is mild, the first seizures of convulsions occur only infrequently and not before the age of 3 months, whereas the monogenic shiverer mutant mice developed this phenotype 1 month after birth (Bird et al., 1978; Chernoff, 1981). The shortened life expectancy of triple mutant mice (7-9 months) compared to the $p l p-/-m b p-/-$ double mutant (life span, 2 years) obviously derives from the additional deprivation of MAG in the myelin of these mutants. In view of the twofold to threefold overexpression of S-MAG in shiverer and $p l p-/-m b p-/-$ double mutants, it is tempting to speculate on a similar role of this MAG isoform for CNS myelin maintenance because it has been shown for PNS myelin (Fujita et al., 1998). $\mathrm{N}-\mathrm{CAM}$ on the other hand, which like MAG is a member of the Ig superfamily, appears not to be involved in this process, although it has been suggested to substitute for the function of MAG in the PNS of MAG-deficient mice (Montag et al., 1994). The double mutant deficient in MAG and N-CAM (Carenini et al., 1997) supported this with regard to axonal and myelin maintenance, but not with regard to myelin formation in the PNS. However, in our study neither the upregulation of the expression of N-CAM120 nor of N-CAM140 was observed in the mutant CNS.

The results of the lipid analysis and the morphological data suggest that the loss of MBP expression causes an impairment of oligodendrocyte development. $\mathrm{GM}_{3}$ besides $\mathrm{GD}_{3}$, and $\mathrm{GD}_{1 \mathrm{a}}$ and $\mathrm{GT}_{1 \mathrm{~b}}$ as minor components, appear to play an important role during the dichotomy of the differentiation of oligodendrocyte precursors. Addition of exogenous $\mathrm{GM}_{3}$ to oligodendrocyte precursors in culture increased the number and the thickness of the oligodendrocyte processes (Yim et al., 1994, 1995). Also the degree of phosphorylation of MBP and MAG is dependent on $\mathrm{GM}_{3} \cdot \mathrm{GM}_{3}$ increases the phosphorylation of MAG and simultaneously reduces MBP phosphorylation (Yim et al., 1994). This observation is of special interest in view of our finding that the gangliosides in CNS myelin of mice with the $m b p-/-$ mutation in general were distinctly decreased, and only $\mathrm{GM}_{3}$ was synthesized by oligodendrocytes of these mutants. Ganglioside $\mathrm{GM}_{1}$ on the other hand is characteristic for isolated myelin of wild type (Suzuki et al., 1967) and is also present in the myelin fraction of all mutants without the shiverer deletion. Mouse myelin isolated from mutants carrying the shiverer allele is deficient in $\mathrm{GM}_{1}$ (Raff et al., 1978; Iwamori et al., 1985).

Gangliosides are markers in oligodendrocyte maturation (Raff et

Figure 3. Electron micrographs of cross-sections through the optic nerves of $m a g-/-$, double mutant (mag-/-plp-l-), and triple mutant (mag-l $-m b p-/-p l p-/-)$ mice. The comparison of the three sections demonstrates the different types of compaction. The axon of the MAG-deficient mouse is surrounded by two distinct myelin sheaths with a normal periodicity. Myelin formation in $p l p-1$ - mag-/ - double mutant is characterized by a decompaction of the IDL as well as by condensed areas with indistinguishable main and intraperiod dense lines. Triple mutants show areas of pseudocompacted myelin around axons with large diameter. No MDL but a pseudo-IDL formed by the compaction of outer surfaces is visible. Scale bar, $200 \mathrm{~nm}$.
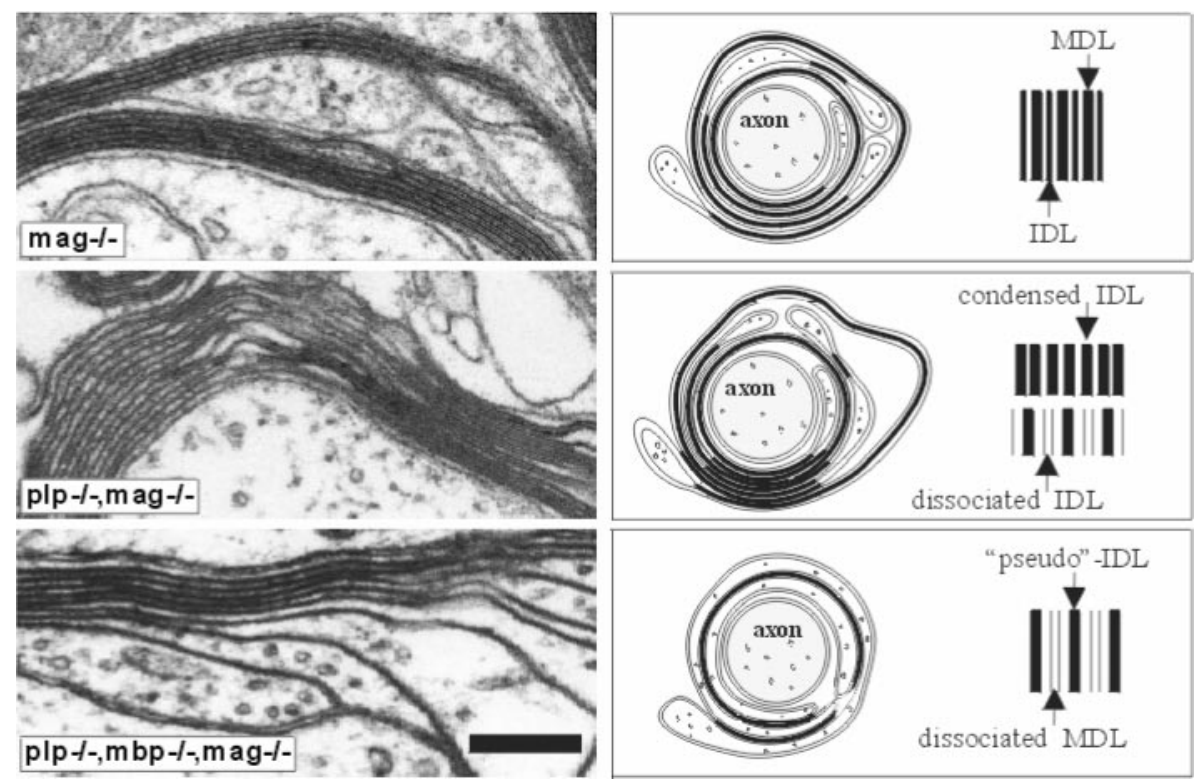

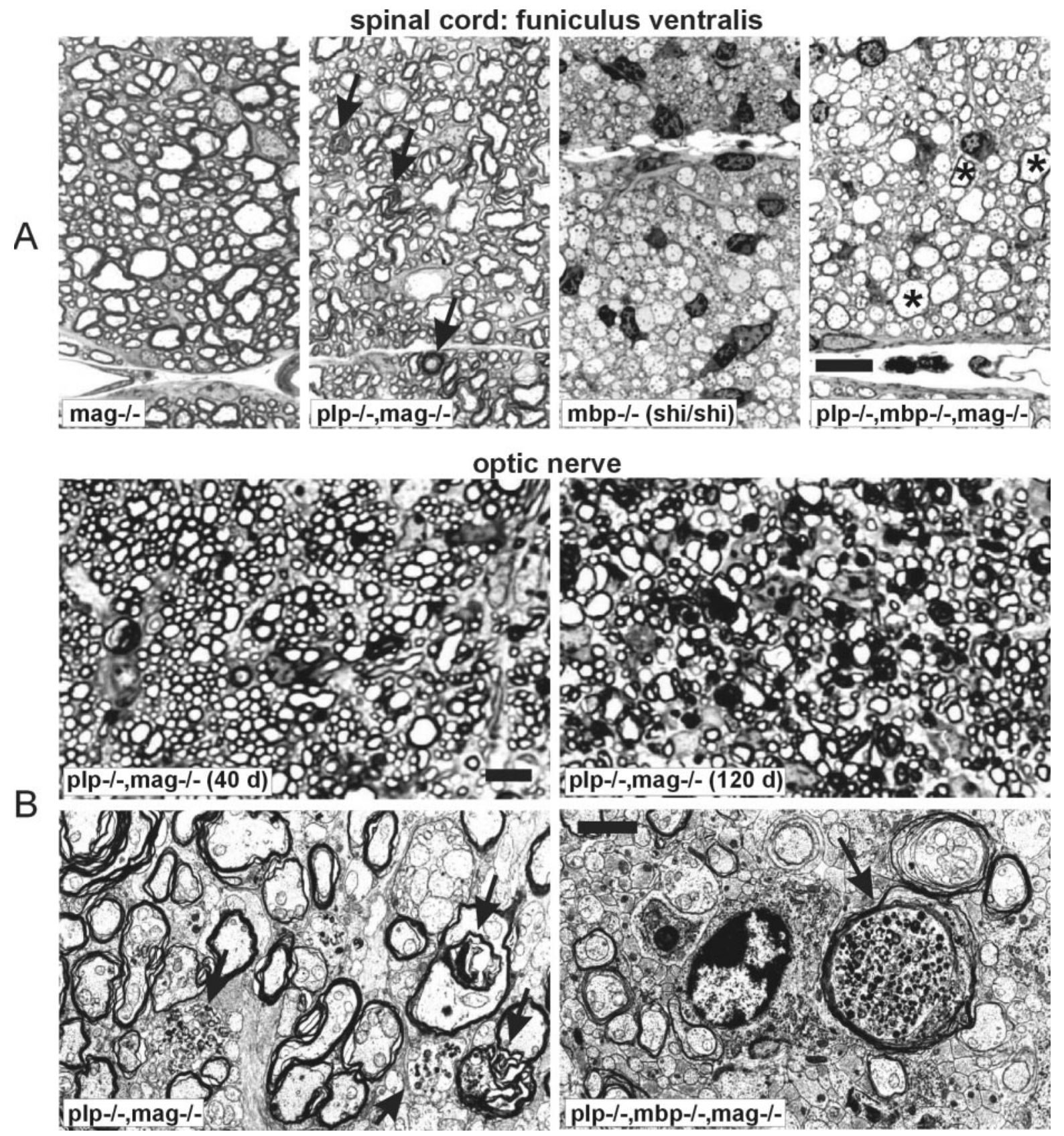

Figure 4. A, Semithin cross-sections of the spinal cord (anterior median fissure) of the indicated genotypes. Whereas mag-/- mice are indistinguishable from $w t$ controls, $p l p-/-m a g-/-$ double mutants have comparable amounts of slightly disordered myelin; in shiverer mice almost no myelin is detectable, whereas in the triple mutant axons with a larger diameter show myelin sheaths (asterisks). Note the increased number of oligodendrocytes in the MBP-deficient animals $(m b p-/-$ and $p l p-/-m b p-/-m a g-/-)$ and axonal degeneration in plp-/-mag-/- double mutant mice (black arrows). Scale bar, $10 \mu \mathrm{m}$. B, Top, Semithin cross-sections of the optic nerve of 40- and 120-d-old plp-/-mag-/- double mutant mice. Note the enlarged number of axonal degeneration with increasing age. Scale bar, $10 \mu \mathrm{m}$. Bottom, Electron micrographs of cross-sections of optic nerve of $p l p-/-m a g-/-$ double mutant and plp-/-mbp-/-mag-/- triple mutant mice (black arrows, axonal degeneration). Scale bar, $2 \mu \mathrm{m}$.

al., 1978; Yim et al., 1994). The ganglioside pattern of myelin of the mutants with the shiverer trait might express a state in the maturation of oligodendrocyte precursor cells. The $p l p-/-m b p-/-$ and $p l p-/-m b p-/-m a g-/-$ triple mutants might be useful models for studies of oligodendrocyte development and maturation.

The array and the results of behavioral tests performed in this study contribute significantly to the characterization of the different phenotypes of the mutants. This becomes most obvious by the analysis of the rather inconspicuous behavior of the mutants containing the mag-/- allele. In the behavioral tests selected in this study, these mice showed a surprisingly poor performance. Although behavioral tests that require motor and reflex responses are known to significantly decline with age (Wallace et al., 1980), and therefore age differences might explain the differences in locomotor activity between our findings and a previous report ( $\mathrm{Li}$ et al., 1994), this effect obviously is caused by the MAG depletion. This suggestion is supported by other behavioral tests because mutants with the mag-/- genotype are affected when they crossed the horizontal bridge during the defined "cutoff" time. Plp-/ - mag $-/-$ mice were hardly able to cling to the horizontal wire because of their motor deficits.

Axonal degeneration is missing in the CNS of mag-/- single mutants. The early onset and rapidly progressing axonal degeneration in CNS of $p l p-/-m a g-/-$ double mutant is demonstrated in electron microscopy of p40 and p120 optic nerves. It parallels the first signs and the progression of the neurological symptoms of this 
Table 7. Genotype and phenotype of myelin mutant mice

Phenotype

\begin{tabular}{|c|c|c|c|c|c|c|}
\hline \multirow[b]{2}{*}{ Genotype } & \multicolumn{6}{|c|}{ Phenotype } \\
\hline & RNA & Protein & Lipid (CNS) & Morphology: myelin & Morphology: axons & $\begin{array}{l}\text { Lifespan } \\
\text { (months) }\end{array}$ \\
\hline $\mathrm{plp}-/-^{a}$ & NA & NA & NA & $\begin{array}{l}\text { Dissociation of outer surfaces, } \\
\text { IDL (CNS) }\end{array}$ & Late onset of degeneration (CNS) & $>24$ \\
\hline $\operatorname{mag}-/-^{b}$ & NA & $\begin{array}{l}\text { MBP } \uparrow \\
(\mathrm{PNS})\end{array}$ & NA & $\begin{array}{l}\text { Reduced cytoplasmic collar, mul- } \\
\text { tiple myelin sheaths (CNS) }\end{array}$ & Late onset of degeneration (PNS) & $>24$ \\
\hline plp $-/-$ mag $-/-$ & NA & $\begin{array}{l}\text { MBP } \uparrow \\
(\mathrm{PNS})\end{array}$ & NA & Phenotype of 1. and 2. & $\begin{array}{l}\text { Early onset of degeneration } \\
\text { (CNS) }\end{array}$ & $>24$ \\
\hline $\mathrm{mbp}-/-^{c}$ & $\begin{array}{l}\mathrm{MAG} \uparrow \\
(\mathrm{CNS})\end{array}$ & NA & $\begin{array}{l}\text { Gangliosides } \downarrow \\
\mathrm{GM}_{3} \uparrow, \\
\text { GalC }+ \text { sGalC } \downarrow\end{array}$ & $\begin{array}{l}\text { Hypomyelination (CNS), } \\
\text { Schmidt-Lantermann-incisures } \\
\text { (PNS) } \uparrow, \text { number of oligoden- } \\
\text { drocytes } \uparrow\end{array}$ & NA & $3-4$ \\
\hline $\mathrm{plp}-/-\mathrm{mbp}-/-^{d}$ & $\begin{array}{l}\mathrm{MAG} \uparrow \\
(\mathrm{CNS})\end{array}$ & NA & $\begin{array}{l}\text { Gangliosides } \downarrow \\
\mathrm{GM}_{3} \uparrow, \\
\mathrm{GalC}+\mathrm{sGalC} \downarrow\end{array}$ & $\begin{array}{l}\text { Hypomyelination (CNS), pseudo- } \\
\text { myelin (CNS), Schmidt-Lanter- } \\
\text { mann-incisures (PNS) } \uparrow, \\
\text { number of oligodendrocytes } \uparrow\end{array}$ & Late onset of degeneration (CNS) & $>24$ \\
\hline $\mathrm{plp}-/-\operatorname{mbp}-/-\operatorname{mag}-/-$ & NA & NA & $\begin{array}{l}\text { Gangliosides } \downarrow, \\
\mathrm{GM}_{3} \uparrow, \\
\mathrm{GalC}+\mathrm{sGalC} \downarrow\end{array}$ & $\begin{array}{l}\text { Hypomyelination (CNS), pseudo- } \\
\text { myelin (CNS), Schmidt-Lanter- } \\
\text { mann-incisures (PNS) } \uparrow, \\
\text { number of oligodendrocytes } \uparrow\end{array}$ & $\begin{array}{l}\text { Early onset of degeneration } \\
\text { (CNS) }\end{array}$ & $7-9$ \\
\hline
\end{tabular}

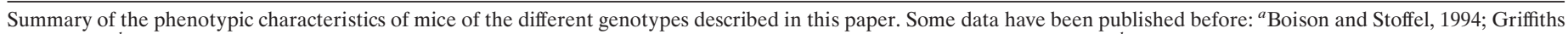
et al., 1998; ${ }^{b} \mathrm{Li}$ et al., 1994; Montag et al., 1994; ${ }^{c}$ Bird et al., 1978; Chernoff, 1981; Gould et al., 1995; Nagara et al., 1983 ; ${ }^{d}$ Stoffel et al., 1997.

NA, Not altered compared to wildtype.

double mutant. This again suggests an important role of MAG in maintaining the integrity of CNS axons similar to the function of MAG in PNS myelin (Fruttiger et al., 1995; Yin et al., 1998). The detrimental effect of MAG deficiency on axons occurs only in the plp-/-mag-/- double mutant.

A recent report discusses the function of a neuron expressed $\mathrm{sr}$ (soma-restricted) PLP in the maintenance of axons (Bongarzone et al., 1999). SrPLP is an alternative splice product of PLP. Exon 1 of srPLP codes for a signal sequence of 11 amino acid residues that resemble strong homology with ER retention signal sequences. The lack of the minor PLP splice product $(2 \%)$ of PLP/DM ${ }_{20}$ is thought to cause the late onset of axonal degeneration in the CNS of the $p l p-/-$ mouse. However, we regard the contribution of srPLP to axonal degeneration as minute compared with the MAG deficiency in the $p l p-/-$ mag $-/-$ double mutant. The additional load of the mag-/- genotype induces dramatically axonal degeneration.

The results reported here strongly suggest that an imbalance of PLP and MBP in favor of PLP in the CNS may downregulate myelin synthesis in oligodendrocytes, because the shiverer phenotype is ameliorated in $p l p-/-m b p-/-$ and $p l p-/-m b p-/$ - mag $-/-$ triple mutant mice. This idea is supported by the phenotype of transgenic mice showing different PLP gene dosage effects, e.g., PLP or $\mathrm{DM}_{20}$ overexpression (Kagawa et al., 1994; Readhead et al., 1994; Johnson et al., 1995).

Plp-/-mag-/- double mutant animals and triple mutant mice lacking two and three important constituents of CNS myelin, respectively, might be valuable models for further studies on how oligodendrocytes function during the assembly of this highly ordered membrane structure. The generation and analysis of these two new mutants strongly indicates the cooperative functions of MAG and PLP in maintaining axon integrity in the CNS.

As a perspective, the double and triple mutants are promising models for stem cell biology and therapy. The recent development in the field of totipotent embryonic and stem cell-derived glial precursor cells and their prospective use as source of cell typespecific somatic precursors for neural implantation has promising perspectives also for efficient myelination and remyelination of axons in CNS. The md rat characterized by a point mutation in exon III of the PLP gene (Thr75 to Pro) (Boison and Stoffel, 1989) and the shaking pup (His36 to Pro) are preferred dysmyelinosis models in transplantation studies (Archer et al., 1997; Brustle et al., 1999). The two models suffer from the short viability of these mutants. The mouse models described and characterized here genetically, biochemically, morphologically, and behaviorally have a considerably longer life span, which recommends them as valuable tools for the long-term evaluation of stem cell therapeutic strategies.

\section{REFERENCES}

Archer DR, Cuddon PA, Lipsitz D, Duncan LD (1997) Myelination of the canine central nervous system by glial cell transplantation: a model for repair of human myelin disease. Nat Med 3:54-59.

Arquint M, Roder J, Chia LS, Down J, Wilkinson D, Bayley H, Braun P, Dunn R (1987) Molecular cloning and primary structure of myelinassociated glycoprotein. Proc Natl Acad Sci USA 84:600-604.

Bird TD, Farrell DF, Sumi SM (1978) Brain lipid composition of the shiverer mouse: (genetic defect in myelin development). J Neurochem 31:387-391.

Bligh E, Dyer W (1959) A rapid method of total lipid extraction and purification. Can J Biochem Physiol 37:911-917.

Boison D, Stoffel W (1989) Myelin-deficient rat: a point mutation in exon III (A-C, Thr75--Pro) of the myelin proteolipid protein causes dysmyelination and oligodendrocyte death. EMBO J 8:3295-302.

Boison D, Stoffel W (1994) Disruption of the compacted myelin sheath of axons of the central nervous system in proteolipid protein-deficient mice. Proc Natl Acad Sci USA 91:11709-11713.

Boison D, Büssow H, D'Urso D, Muller HW, Stoffel W (1995) Adhesive properties of proteolipid protein are responsible for the compaction of CNS myelin sheaths. J Neurosci 15:5502-5513.

Bongarzone ER, Campagnoni CW, Kampf K, Jacobs EC, Handley VW, Schonmann V, Campagnoni AT (1999) Identification of a new exon in the myelin proteolipid protein gene encoding novel protein isoforms that are restricted to the somata of oligodendrocytes and neurons [In Process Citation]. J Neurosci 19:8349-8357.

Brustle O, Jones KN, Learish RD, Karram K, Choudhary K, Wiestler OD, Duncan ID, McKay RD (1999) Embryonic stem cell-derived glial precursors: a source of myelinating transplants [see comments]. Science 285:754-756.

Büssow H (1978) Schwann cell myelin ensheathing CNS axons in the nerve fibre layer of the cat retina. J Neurocytol 7:207-214.

Cammer W, Kahn S, Zimmerman T (1984) Biochemical abnormalities in spinal cord myelin and CNS homogenates in heterozygotes affected by the shiverer mutation. J Neurochem 42:1372-1378.

Carenini S, Montag D, Cremer H, Schachner M, Martini R (1997) Absence of the myelin-associated glycoprotein (MAG) and the neural cell 
adhesion molecule (N-CAM) interferes with the maintenance, but not with the formation of peripheral myelin. Cell Tissue Res 287:3-9.

Chernoff GF (1981) Shiverer: an autosomal recessive mutant mouse with myelin deficiency. J Hered 72:128.

Chomczynski P, Sacchi N (1987) Single-step method of RNA isolation by acid guanidinium thiocyanate- phenol-chloroform extraction. Anal Biochem 162:156-159.

Fruttiger M, Montag D, Schachner M, Martini R (1995) Crucial role for the myelin-associated glycoprotein in the maintenance of axon-myelin integrity. Eur J Neurosci 7:511-515.

Fujita N, Kemper A, Dupree J, Nakayasu H, Bartsch U, Schachner M, Maeda N, Suzuki K, Popko B (1998) The cytoplasmic domain of the large myelin-associated glycoprotein isoform is needed for proper CNS but not peripheral nervous system myelination. J Neurosci 18:1970-1978.

Gould RM, Byrd AL, Barbarese E (1995) The number of SchmidtLanterman incisures is more than doubled in shiverer PNS myelin sheaths. J Neurocytol 24:85-98.

Griffiths I, Klugmann M, Anderson T, Yool D, Thomson C, Schwab MH, Schneider A, Zimmermann F, McCulloch M, Nadon N, Nave KA (1998) Axonal swellings and degeneration in mice lacking the major proteolipid of myelin. Science 280:1610-1613.

Inuzuka T, Fujita N, Sato S, Baba H, Nakano R, Ishiguro H, Miyatake T (1991) Expression of the large myelin-associated glycoprotein isoform during the development in the mouse peripheral nervous system. Brain Res 562:173-175.

Iwamori M, Harpin ML, Lachapelle F, Baumann N (1985) Brain gangliosides of quaking and shiverer mutants: qualitative and quantitative changes of monosialogangliosides in the quaking brain. J Neurochem 45:73-78.

Johnson RS, Roder JC, Riordan JR (1995) Over-expression of the DM-20 myelin proteolipid causes central nervous system demyelination in transgenic mice. J Neurochem 64:967-976.

Kagawa T, Ikenaka K, Inoue Y, Kuriyama S, Tsujii T, Nakao J, Nakajima K, Aruga J, Okano H, Mikoshiba K (1994) Glial cell degeneration and hypomyelination caused by overexpression of myelin proteolipid protein gene. Neuron 13:427-442.

Klapdor K, van der Staay FJ (1996) The Morris water-escape task in mice: strain differences and effects of intra-maze contrast and brightness. Physiol Behav 60:1247-1254.

Klapdor K, van der Staay FJ (1998) Repeated acquisition of a spatial navigation task in mice: effects of spacing of trials and of unilateral middle cerebral artery occlusion. Physiol Behav 63:903-909.

Klugmann M, Schwab MH, Puhlhofer A, Schneider A, Zimmermann F, Griffiths IR, Nave KA (1997) Assembly of CNS myelin in the absence of proteolipid protein. Neuron 18:59-70.

Kuhn PL, Petroulakis E, Zazanis GA, McKinnon RD (1995) Motor function analysis of myelin mutant mice using a rotarod. Int J Dev Neurosci 13:715-722.

Lai C, Brow MA, Nave KA, Noronha AB, Quarles RH, Bloom FE, Milner RJ, Sutcliffe JG (1987) Two forms of 1B236/myelin-associated glycoprotein, a cell adhesion molecule for postnatal neural development, are produced by alternative splicing. Proc Natl Acad Sci USA 84:4337-4341.

Lees M, Brostoff SW (1984) Proteins of myelin. New York: Plenum.

Li C, Tropak MB, Gerlai R, Clapoff S, Abramow-Newerly W, Trapp B, Peterson A, Roder J (1994) Myelination in the absence of myelinassociated glycoprotein. Nature 369:747-750.

Molineaux SM, Engh H, de Ferra F, Hudson L, Lazzarini RA (1986) Recombination within the myelin basic protein gene created the dysmyelinating shiverer mouse mutation. Proc Natl Acad Sci USA 83:7542-7546.

Montag D, Giese KP, Bartsch U, Martini R, Lang Y, Bluthmann H, Karthigasan J, Kirschner DA, Wintergerst ES, Nave KA (1994) Mice deficient for the myelin-associated glycoprotein show subtle abnormalities in myelin. Neuron 13:229-246.

Morris R (1984) Developments of a water-maze procedure for studying spatial learning in the rat. J Neurosci Methods 11:47-60.
Nagara H, Suzuki K, Tateishi J (1983) Radial component of central myelin in shiverer mouse. Brain Res 263:336-339.

Nave KA, Lai C, Bloom FE, Milner RJ (1986) Jimpy mutant mouse: a 74-base deletion in the mRNA for myelin proteolipid protein and evidence for a primary defect in RNA splicing. Proc Natl Acad Sci USA 83:9264-9268.

Norton WT, Poduslo SE (1973) Myelination in rat brain: method of myelin isolation. J Neurochem 21:749-757.

Omlin FX, Webster HD, Palkovits CG, Cohen SR (1982) Immunocytochemical localization of basic protein in major dense line regions of central and peripheral myelin. J Cell Biol 95:242-248.

Pedraza L, Frey AB, Hempstead BL, Colman DR, Salzer JL (1991) Differential expression of MAG isoforms during development. J Neurosci Res 29:141-148.

Raff MC, Mirsky R, Fields KL, Lisak RP, Dorfman SH, Silberberg DH, Gregson NA, Leibowitz S, Kennedy MC (1978) Galactocerebroside is a specific cell-surface antigenic marker for oligodendrocytes in culture. Nature 274:813-816.

Readhead C, Schneider A, Griffiths I, Nave KA (1994) Premature arrest of myelin formation in transgenic mice with increased proteolipid protein gene dosage. Neuron 12:583-595.

Roach A, Takahashi N, Pravtcheva D, Ruddle F, Hood L (1985) Chromosomal mapping of mouse myelin basic protein gene and structure and transcription of the partially deleted gene in shiverer mutant mice. Cell 42:149-155.

Rosenbluth J (1980) Peripheral myelin in the mouse mutant Shiverer. J Comp Neurol 193:729-739.

Schneider A, Montague P, Griffiths I, Fanarraga M, Kennedy P, Brophy P, Nave KA (1992) Uncoupling of hypomyelination and glial cell death by a mutation in the proteolipid protein gene. Nature 358:758-761.

Schulte S, Stoffel W (1993) Ceramide UDPgalactosyltransferase from myelinating rat brain: purification, cloning, and expression. Proc Natl Acad Sci USA 90:10265-10269.

Stoffel W, Hillen H, Giersiefen H (1984) Structure and molecular arrangement of proteolipid protein of central nervous system myelin. Proc Natl Acad Sci USA 81:5012-5016.

Stoffel W, Boison D, Bussow H (1997) Functional analysis in vivo of the double mutant mouse deficient in both proteolipid protein (PLP) and myelin basic protein (MBP) in the central nervous system. Cell Tissue Res 289:195-206.

Suzuki K, Poduslo SE, Norton WT (1967) Gangliosides in the myelin fraction of developing rats. Biochim Biophys Acta 144:375-381.

Towbin H, Staehelin T, Gordon J (1979) Electrophoretic transfer of proteins from polyacrylamide gels to nitrocellulose sheets: procedure and some applications. Proc Natl Acad Sci USA 76:4350-4354.

Trapp BD (1990) Myelin-associated glycoprotein. Location and potential functions. Ann NY Acad Sci 605:29-43.

Tropak MB, Johnson PW, Dunn RJ, Roder JC (1988) Differential splicing of MAG transcripts during CNS and PNS development. Brain Res 464:143-155.

Wallace JE, Krauter EE, Campbell BA (1980) Motor and reflexive behavior in the aging rat. J Gerontol 35:364-370.

Weimbs T, Stoffel W (1992) Proteolipid protein (PLP) of CNS myelin: positions of free, disulfide- bonded, and fatty acid thioester-linked cysteine residues and implications for the membrane topology of PLP Biochemistry 31:12289-12296.

Yim SH, Farrer RG, Hammer JA, Yavin E, Quarles RH (1994) Differentiation of oligodendrocytes cultured from developing rat brain is enhanced by exogenous GM3 ganglioside. J Neurosci Res 38:268-281.

Yim SH, Farrer RG, Quarles RH (1995) Expression of glycolipids and myelin-associated glycoprotein during the differentiation of oligodendrocytes: comparison of the CG-4 glial cell line to primary cultures. Dev Neurosci 17:171-180.

Yin X, Crawford TO, Griffin JW, Tu P, Lee VM, Li C, Roder J, Trapp BD (1998) Myelin-associated glycoprotein is a myelin signal that modulates the caliber of myelinated axons. J Neurosci 18:1953-1962. 